\title{
Changes in oviducal vascularity during the reproductive cycle of three oviparous lizards (Eumeces obsoletus, Sceloporus undulatus and Crotaphytus collaris)*
}

\author{
G. R. Masson $\uparrow \S$ and L. J. Guillette, Jr $\ddagger$ \\ $\dagger$ Department of Biological Sciences, Wichita State University, Wichita, KS 67208, and \\ $\ddagger$ Department of Zoology, University of Florida, Gainesville, FL 32611, U.S.A.
}

\begin{abstract}
Summary. Histologically derived estimates and ink suspension vascular casts were used to examine oviducal vascular changes. Vascularity peaked during gravidity and was correlated with maximal plasma progesterone concentrations. The vascular increase in the oviducal tissue was attributed exclusively to increased capillary densities. The greatest change occurred in the anterior uterus where incubation and egg shell secretion occur. Similar patterns of change in vascularity occurred in the infundibulum, although not as extreme as that seen in the anterior uterus, whereas no significant alterations were noted in the posterior uterus. These modifications mimic the pattern of vascular change occurring in viviparous lizards during simple placentation. We suggest that major changes in uterine vascularity may not be required for the evolution of simple chorioallantoic placentae in lizards.
\end{abstract}

\section{Introduction}

Temperate-zone squamates exhibit seasonal reproductive activity (Duvall et al., 1982; Licht, 1984). Follicular development is accompanied by an hypertrophy of the oviduct. The reptilian oviduct (defined as all structures derived from the embryonic Müllerian duct system) has been subdivided into several distinct regions including: the infundibulum (homologous to the mammalian oviduct), anterior uterus (region of shell glands) and posterior uterus (Fox, 1977; Guillette \& Jones, 1985).

Exogenous administration of oestrogens to ovariectomized lizards in a manner similar to the natural reproductive cycle cause hypertrophy of the oviduct (Yaron, 1972; Christiansen, 1973; Veith, 1974; Fawcett, 1975; Mead et al., 1981). Progesterone maintains the oviducts in some reptilian species (Veith, 1974), whereas it works synergistically with oestrogens in others (Fawcett, 1975; Mead et al., 1981).

Vascular changes during the reproductive cycle of oviparous and viviparous lizards (Guraya \& Varma, 1974; Fox, 1984; Guillette \& Jones, 1985; Yaron, 1985) occur primarily in the number of capillaries and in the size of the arteries and veins (Guillette \& Jones, 1985; Yaron, 1985). Fox (1984) observed that vascularity decreased throughout gravidity in the oviparous lizard, Crotaphytus collaris, whereas in the egg-retaining lizard species, Eumeces obsoletus, a decrease in vascularity was not noted until late gravidity. In the egg-retaining oviparous lizard, Sceloporus aeneus, however, there is an increase in oviducal vascularity during gravidity similar to that occurring in the closely related viviparous species, S. bicanthalis (Guillette \& Jones, 1985). Gerrard (1974) observed a very vascular uterus in the viviparous snake, Thamnophis radix haydenii, just

\footnotetext{
${ }^{*}$ Reprint requests to $\mathrm{Dr} \mathrm{L}$. J. Guillette, Jr.

§Present address: Department of Zoology, University of Florida, Gainesville, FL 32611, U.S.A.
} 
before ovulation, which was maintained as an increase in branching and size of the vessels until a slight decline occurred during the last third of embryonic development in utero.

In the studies indicated above oviducal vascularity was estimated from gross anatomical examination or from serial histological sections. However, only those capillaries having red blood cells usually stain and thus become recognizable. Additionally, this method does not allow for the differential analysis of vessel size or changes in structure (i.e. tapering of vessels, or their expansion), and tortuous vessels may be counted more than once or not at all. Moreover, an histological approach has the additional drawback of being a two-dimensional expression of a three-dimensional structure. Vascular casting studies using injections of India ink (Soewarmoto \& Bern, 1958), and/or low-viscosity rubber silicone material (Hunsuck, 1968; Larson \& Van de Velder, 1969; Jones et al., 1983) allow gross quantification of blood vessel types and densities. Furthermore, the ink injections do not preclude histological examination.

The present study examined whether (1) oviducal vascularity increases during gravidity in oviparous lizard species; (2) if hypervascularity occurs, is the increase similar to that observed in viviparous forms having simple placentae; and (3) blood vessels of all sizes participate in producing oviducal hypervascularity?

\section{Materials and Methods}

\section{Study animals}

The oviparous lizards examined were Crotaphytus collaris (the collared lizard), Sceloporus undulatus (the eastern fence lizard), and Eumeces obsoletus (the great plains skink). The reproductive biology of these three species has been sporadically studied (Brooks, 1906; Fitch, 1955, 1956; Hall, 1971, 1972; Trauth, 1978; Fox, 1984). All three exhibit spring gonadal development and mating occurs soon after emergence from winter inactivity. The collared lizard and the eastern fence lizard produce multiple clutches (Fitch, 1955, 1956; Trauth, 1978; Fox, 1984) whereas great plains skinks retain their eggs in utero until embryonic development is relatively advanced and so have only one clutch per year.

Mature females of all 3 species were captured during the spring, summer, and fall of 1984 in Sedgwick, Butler and Cowley counties, Kansas. Maturity was determined by snout-vent length for each species (Fitch, 1970; Fox, 1984). The size of reproductively active female collared lizards (C. collaris) and skinks (E. obsoletus) in this study was 69.0$96.8 \mathrm{~mm}$ and $90.8-122.5 \mathrm{~mm}$ snout-vent length, respectively. Reproductively active female fence lizards $(S$. undulatus $)$ exhibited a size range of $46.0-64.8 \mathrm{~mm}$ snout-vent length. Four different stages of reproductive activity were examined: (1) non-reproductive, i.e. no vitellogenic follicles or oviducal eggs present, (2) vitellogenic, i.e. vitellogenic follicles but no oviducal eggs, (3) gravid, i.e. non-vitellogenic ovarian follicles and oviducal eggs, and (4) post-gravid, i.e. no vitellogenic follicles or oviducal eggs but distended oviducts present.

\section{Blood collection and radioimmunoassay}

The animals were processed within $24 \mathrm{~h}$ of capture and body weights and snout-vent length were recorded. The lizards were anaesthetized with pentobarbitone sodium $(0.025 \mathrm{mg}$; Searle, Chicago, IL) and a ventro-lateral incision was made to allow unimpeded access to the ventricle. Before injection of the casting material, a blood sample (1.5$2.0 \mathrm{ml}$ ) was withdrawn and stored at $-20^{\circ} \mathrm{C}$ for later determination of plasma progesterone concentration using a specific radioimmunoassay (RIA) validated for these lizards (Guillette et al., 1981). Plasma samples were extracted in duplicate with ethyl ether, and dried under nitrogen at $37^{\circ} \mathrm{C}$. Extraction efficiency averaged $89 \cdot 7 \%$. Progesterone antiserum, anti-progesterone-11-BSA (G. D. Niswender, Colorado State University) was added to each sample at a concentration of 1:4500. The competitor $\left[1,2,6,7,16,17 \cdot{ }^{3} \mathrm{H}\right]$ progesterone was obtained from Amersham Corporation (Arlington Heights, $\mathrm{NJ}$ ). Dextran-coated charcoal was used to separate bound from free progesterone. Average binding was $40 \cdot 3 \%$ with $1.6 \%$ being non-specific. Intra-assay variability was calculated from replicates $(n=10)$ of a plasma pool and was low (coefficient of variation $=4.0 \%$ ). The assay sensitivity, the smallest amount significantly different from zero, was $10 \mathrm{pg} /$ tube.

\section{Vascular casts}

Vascular casts were made using a non-toxic suspension of India ink (Higgins Eternal Ink, No. 613) in lizard Ringer's solution (Guillette, 1982b). The infusion of the India ink suspension was at approximately physiological pressure $(50 \mathrm{mmHg}$; Baker et al., 1972). Preparation of the India ink for injection was made using the methods of Soewarmoto \& Bern (1958). The ink was centrifuged in $20 \mathrm{ml}$ aliquants at $4^{\circ} \mathrm{C}$, using a Sorval ultracentrifuge. The 
first centrifugation was at $1750 \mathrm{~g}$ for $1 \mathrm{~h}$. The initial pellet of large particles was discarded and the supernatant was saved for a second centrifugation at $18000 \mathrm{~g}$ for $1.5 \mathrm{~h}$. The supernatant from this centrifugation was discarded. The pellet from the second centrifugation was resuspended in lizard Ringer's solution (Guillette, 1982b) in a volume equal to one third of the volume of the first supernatant. Just before injection, this stock solution was diluted with heparinized $(0.075 \%)$ lizard Ringer's solution to the original volume of the first supernatant. Small amounts of ink solution $(1.5-2.0 \mathrm{ml})$ were introduced during diastole into the ventricle just lateral to the apex of the lizard's heart with a 25-gauge needle on a 2-ml syringe. The needle was placed through the ventricle to within $1-2 \mathrm{~mm}$ of the systemic aorta to ensure good perfusion without pooling of the injection fluid. The infusion proceeded over a period of $20 \mathrm{~min}$ to allow capillary filling. When the perfusion was complete, the heart was injected with $0.05 \mathrm{ml} 0.1 \% \mathrm{KCl}$ to cause hyperpolarization and cessation of beating. The specimens then were placed in a refrigerator for $2-3 \mathrm{~h}$ to allow the ink injection to stabilize within the vessels.

The right oviduct and ovary were dissected out and pinned out on paraffin wax discs. The tissue was cleared by immersion (each of $24 \mathrm{~h}$ duration) in: (1) $50 \%$ glycerin and water, (2) $75 \%$ glycerin and water, (3) $85 \%$ glycerin and water, and (4) $100 \%$ glycerin. The tissues were stored in $100 \%$ glycerin.

\section{Oviducal histology}

The left oviduct and ovary were dissected free and fixed in $10 \%$ neutral buffered formalin. Normal histological procedures were used (Humason, 1979). Ovaries without large yolky follicles and oviducts were embedded in paraffin wax, serially sectioned at $10 \mu \mathrm{m}$ and stained with Alcian Blue and counterstained with haematoxylin and eosin, or with Mallory's trichrome (Humason, 1979). Ovaries with large yolky follicles as well as oviducts containing eggs were prepared after fixation in 10\% neutral buffered formalin by using the methods of Yaron (1971) with the modifications of Fox (1984). These modifications included: (1) increasing tissue exposure to three changes of $N$-butanol from $2 \times 3 \mathrm{~h}$ and $15 \mathrm{~h}$, to $2 \times 4 \mathrm{~h}$ and $24 \mathrm{~h}$, and (2) increasing the three periods of vacuum infiltration in paraffin wax from $3 \times 1 \mathrm{~h}$ to $2 \times 2 \mathrm{~h}$ and $3 \mathrm{~h}$. These changes produced paraffin wax-embedded tissues which could be serially sectioned at $10 \mu \mathrm{m}$.

Oviducal morphology was qualified and quantified by two methods. The first used the methods of Guillette \& Jones (1985) by which an estimate of oviducal vascular density was obtained from histological sections by counting the number of vessels which were relatively ovoid and filled with ink within an area visualized with an ocular grid at $\times 40\left(0.5 \mathrm{~mm}^{2}\right)$. For each oviducal region (infundibulum, anterior uterus, posterior uterus) values were obtained from 10 different, randomly selected histological sections. Values from like species exhibiting the same reproductive stage then were averaged to obtain a stage mean and s.e.

The second method utilized a dissecting microscope and the cleared right oviducts with ink casts. An ocular grid was used to visualize $(\times 20)$ the oviduct so that 4 counts could be made on randomly selected areas $\left(4 \mathrm{~mm}^{2}\right)$ of the anterior uterus. The dorsal artery and vein were used as guides for grid placement with the grids' lateral border placed alongside these large vessels. The vessels were divided into four categories by their relative size and anastomoses. The largest of these circumoviducal vessels were termed primary $\left(1^{\circ}\right)$ vessels, slightly smaller vessels which branched from the $1^{\circ}$ vessels were labelled secondary $\left(2^{\circ}\right)$ vessels which branched into smaller tertiary $\left(3^{\circ}\right)$ vessels. The $3^{\circ}$ vessels either joined with other $3^{\circ}$ vessels to form arteriole-venule anastomoses or they branched into small capillaries $\left(4^{\circ}\right.$ vessels). The mean counts per area of each oviduct within a reproductive stage were converted to the unit blood vessels $/ \mathrm{mm}^{2}$ and then used to determine a stage $\times$ vessel type mean $( \pm$ s.e.). Values for each stage within each species were compared using one-way ANOVA followed by Duncan's New Multiple range tests. A value of $P<0.05$ was considered statistically significant.

\section{Results}

\section{General morphology}

The oviducts of all 3 species were typical of oviparous squamate reptiles. Using gross anatomy, three regions were discernible: (1) infundibulum, (2) anterior uterus (shell gland region), and (3) posterior uterus. The non-reproductively active females of all 3 species exhibited relatively short ( $<10 \%$ snout-vent length) oviducts which did not exhibit hypertrophy of the luminal epithelium or lamina propria. Vitellogenic animals had a longer oviduct ( $>10 \%$ snout-vent length) and an increased luminal epithelial cell height ( $>20 \%$ of that of non-reproductively active females) of the infundibular and uterine regions. The oviducts of gravid animals were much enlarged (due to the presence of eggs) and both epithelial cell height and gland size increased in the infundibular and anterior uterine regions. The posterior uterus changed very little during the reproductive cycle. However, there was a generalized increase in size of the oviduct which included hypertrophy and hyperplasia of oviducal cells. The post-gravid animals had flaccid oviducts that were enlarged compared to those of early non-reproductive females. 


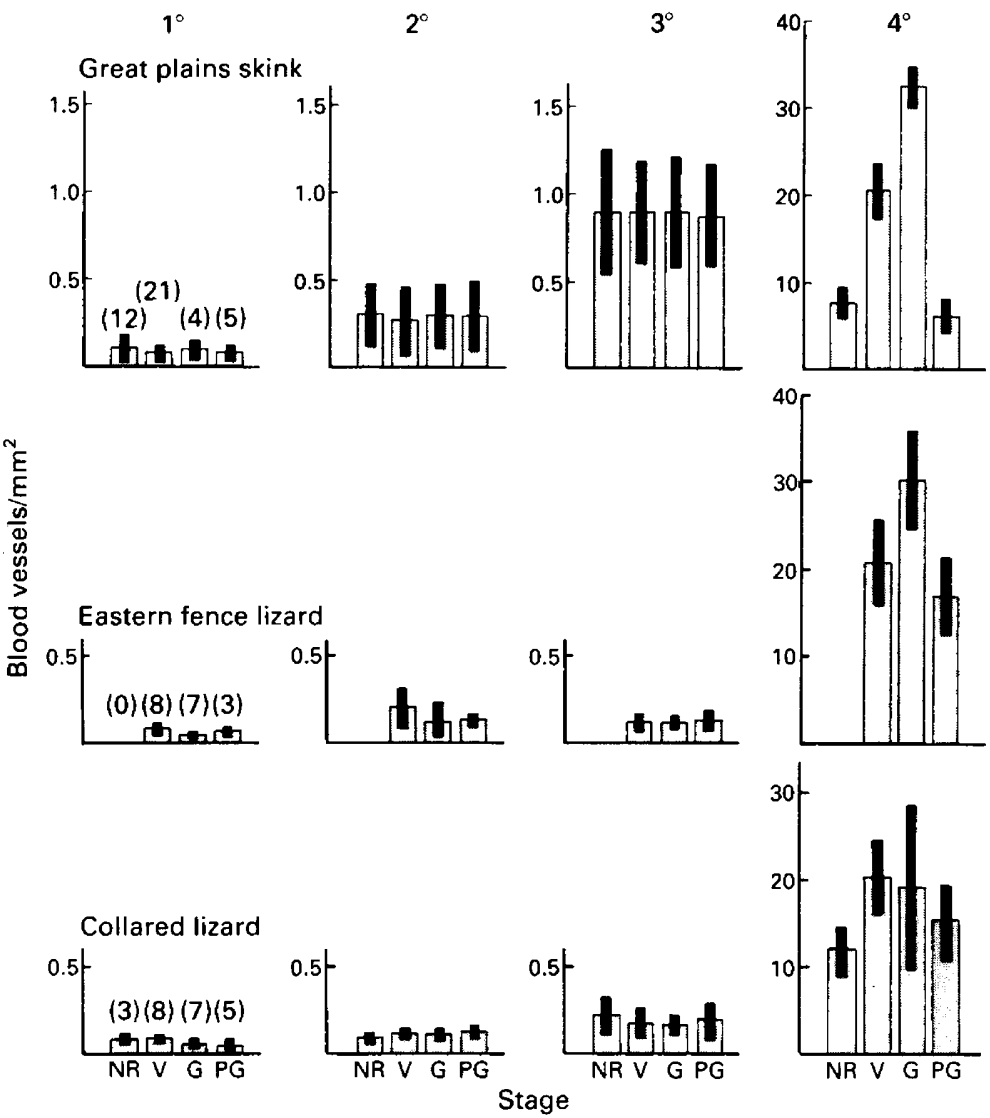

Fig. 1. Mean ( \pm s.e.) oviducal density of four size classes of blood vessels during four stages of reproductive activity ( $\mathrm{NR}=$ non-reproductive; $\mathrm{V}=$ vitellogenic; $\mathrm{G}=$ gravid; $\mathrm{PG}=$ postgravid) in great plains skinks (Eumeces obsoletus), eastern fence lizards (Sceloporus undulatus) and collared lizards (Crotaphytus collaris). The sizes of the groups are given in parentheses in the first panel. Note scale change in values for $4^{\circ}$ vessels (see text for vessel sizes).

\section{Vascular casts}

The ink injections revealed a posterior to anterior filling of the oviducts along the dorsal uterine artery. From this vessel, the suspension flowed approximately equally in a lateral and medial direction around the oviduct. In each species, the tertiary arterioles branched into a capillary bed, but also there were arteriole-venule anastomoses in each reproductive stage. No change in the density of the $1^{\circ}, 2^{\circ}$ or $3^{\circ}$ blood vessels was noted in any species (Fig. 1). Only the capillaries exhibited changes associated with reproductive stage (see Fig. 2). Capillary density increased during vitellogenesis and gravidity in great plains skinks (Figs 1 \& 2) and collared lizards (Fig. 1). Maximal values 30·7-32.6 were similar to values (32-35) obtained using histological estimates for the anterior uterus. Oviducal vascular density was positively correlated with plasma progesterone concentration in great plains skinks $(r=0.68, P<0.01)$ and collared lizards $(r=0.54, P<0.01)$. A correlation coefficient could not be calculated for eastern fence lizards because of missing values.

\section{Vascular histology}

Mean capillary densities only were obtained. These counts were made for each stage of the reproductive cycle for each species. The counts were made of those vessels which were round (cut in 

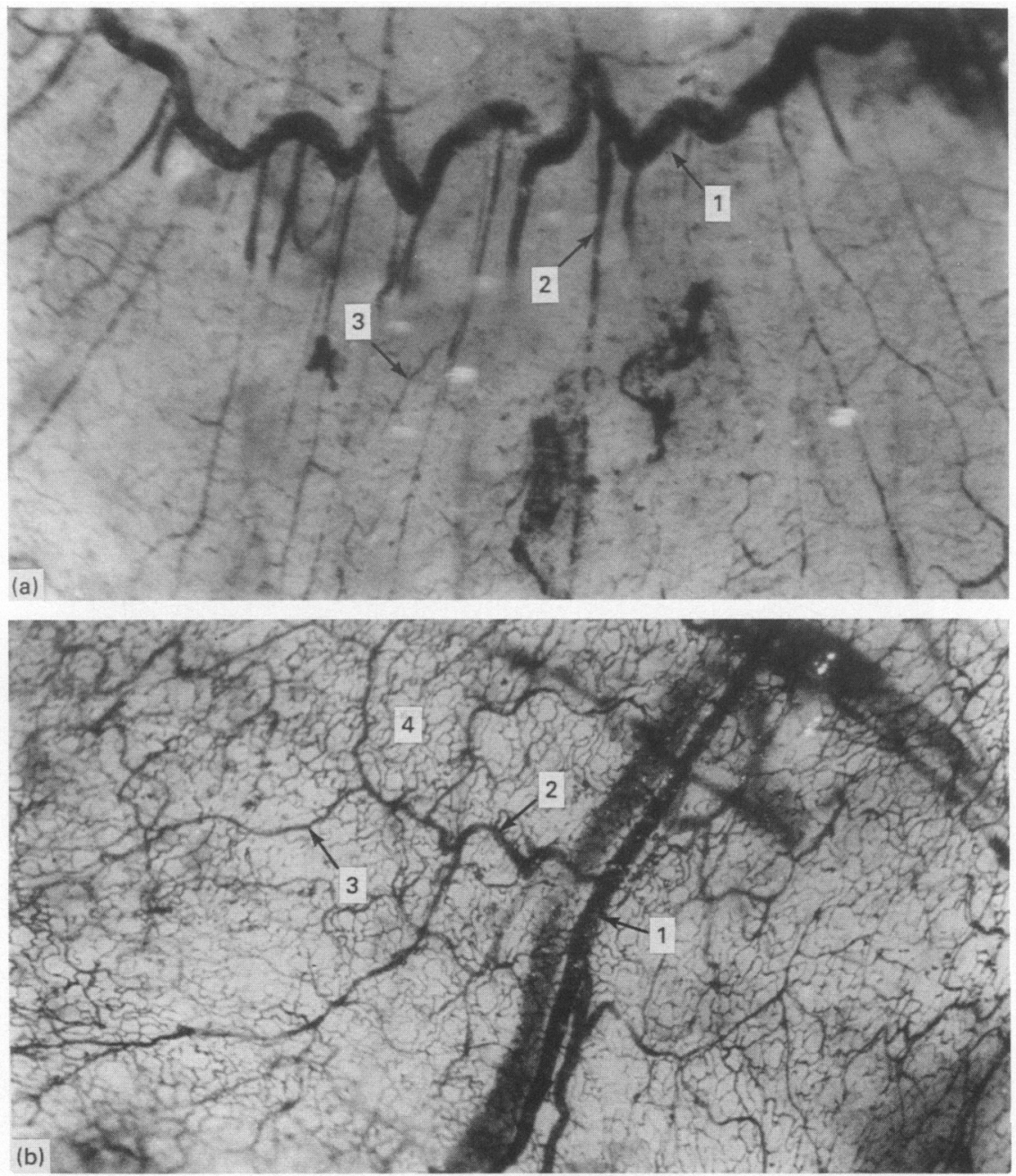

Fig. 2. Photomicrographs of ink-injected oviducal tissue from great plains skinks cleared with glycerin: (a) anterior uterus from a non-reproductively active female; (b) anterior uterus from a vitellogenic female. 1 = main uterine artery and/or vein; $2=$ secondary blood vessels; $3=$ tertiary blood vessels; $4=$ capillary beds.

cross-section) and contained the carbon black particles of the India ink injection (see Fig. 3). The capillaries were located primarily between the luminal epithelial cells and the lamina propria (Fig. 3 ). Density changes were observed within the region of the infundibulum and in close proximity to the shell glands of the anterior uterus (Fig. 4).

Great plains skinks. The capillaries changed in mean number during the vitellogenic and gravid stages of reproduction (Fig. 4). In the infundibular region, vitellogenic females had capillary densities $\times 2.5$ greater than those of the non-reproductively active females. The post-gravid females exhibited a mean capillary density equal to that of non-reproductively active animals. The greatest density of capillaries was found in the gravid females which exhibited values significantly greater than females at all other reproductive stages $(\mathrm{F}(3,20)=11.79, P<0.01)$.

Within the anterior uterine region, only the gravid females showed a significant increase in capillary concentration (Fig. 4). The density of capillaries of the posterior uterine region exhibited no change with reproductive activity (Fig. 4 ). 

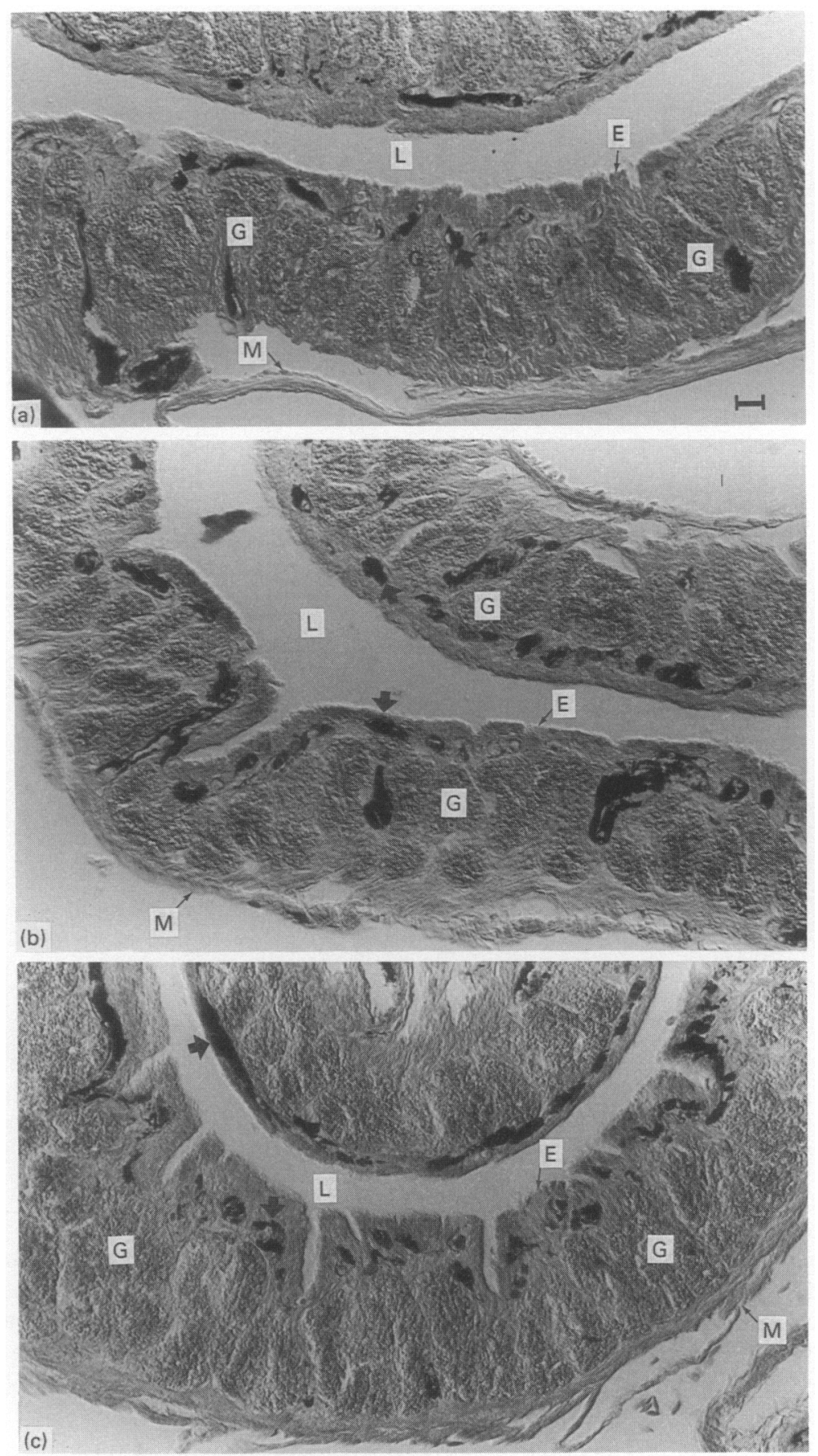

Fig. 3. Photomicrographs of histological sections through ink-injected anterior uterine tissue from great plains skinks (Mallory's trichrome staining with DIC microscopy): (a) nonreproductive; (b) vitellogenic; (c) gravid. $\mathrm{E}=$ oviducal epithelium; $\mathrm{G}=$ uterine glands; $\mathrm{L}=$ oviducal lumen; $\mathrm{M}=$ myometrium. Blood vessels are represented by dark ink-filled vessels (see arrows). Bar $=10 \mu \mathrm{m}$. 


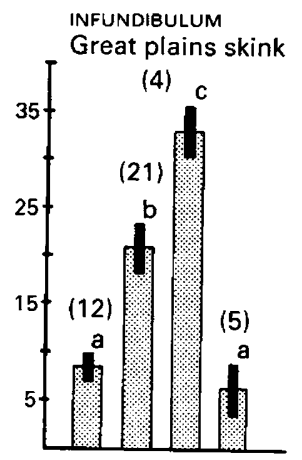

ANTERIOR UTERUS

POSTERIOR UTERUS
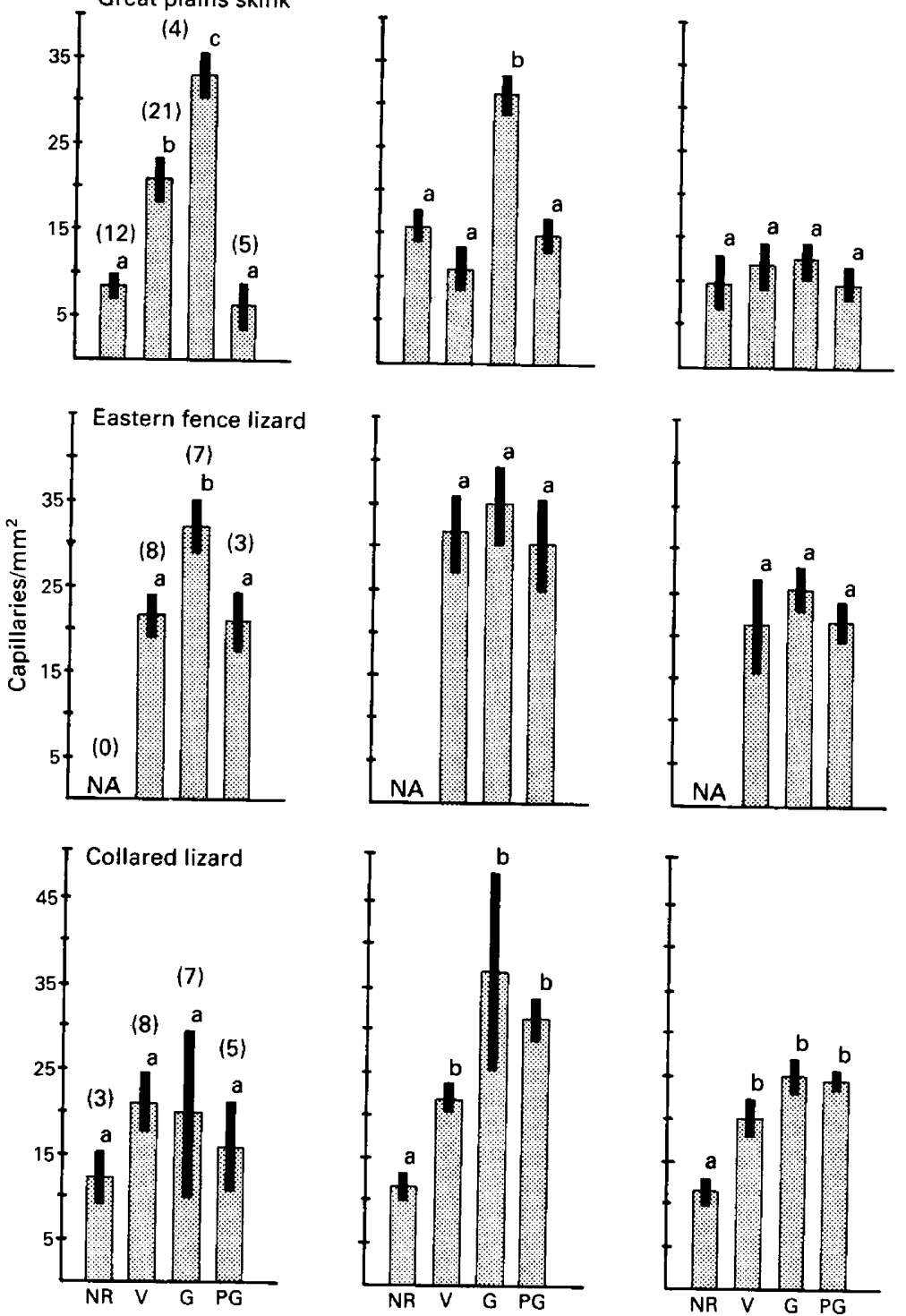

Fig. 4. Mean ( \pm s.e., no. of animals in parentheses) capillary density as determined by histological estimates in three regions of the oviduct at four stages of reproductive activity in the great plains skink (Eumeces obsoletus), eastern fence lizard (Sceloporus undulatus) and collared lizard (Crotaphytus collaris). $\mathrm{NR}=$ non-reproductive; $\mathrm{V}=$ vitellogenic; $\mathrm{G}=$ gravid; $\mathrm{PG}=$ post-gravid. Within each panel, values with different superscripts and significantly different $(P<0.05)$.

Fence lizards. Like great plains skinks, gravid females had a greater capillary density in the infundibulum than did vitellogenic or post-gravid females (Fig. 4). The anterior and posterior uterine regions showed little or no change with reproductive condition although a high density of capillaries overall was exhibited. 


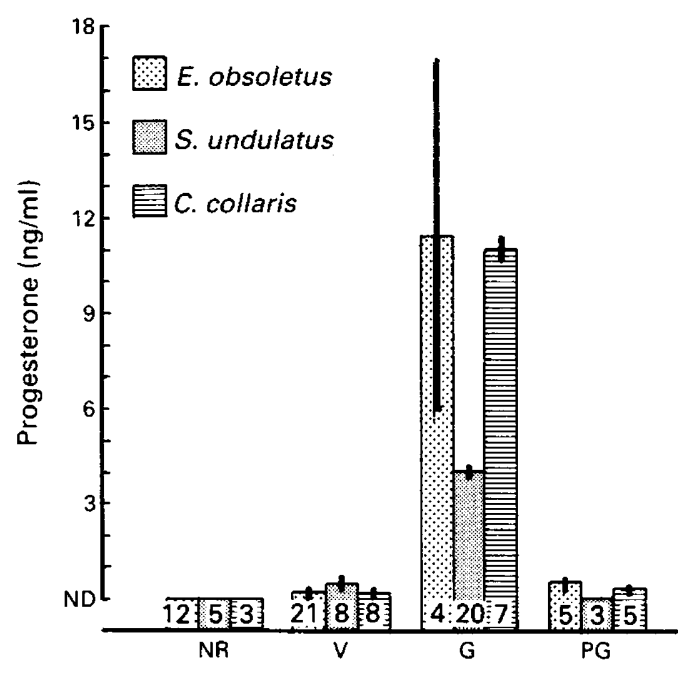

Fig. 5. Mean ( \pm s.e., no of animals indicated) plasma progesterone concentrations for three oviparous lizards during four stages of reproductive activity $(\mathrm{NR}=$ non-reproductive; $\mathrm{V}=$ vitellogenic; $\mathrm{G}=$ gravid; $\mathrm{PG}=$ post-gravid $) . \mathrm{ND}=$ non-detectable $(<0.01 \mathrm{ng} / \mathrm{ml})$.

Collared lizards. Due to the large variation in density, especially during gravidity, there was no significant difference among reproductive stages in the infundibulum (Fig. 4). In the anterior and posterior uterine regions the non-reproductively active females had significantly fewer capillaries than did the other groups.

\section{Plasma progesterone concentration}

Values increased significantly during gravidity in all three species (Fig. 5). Concentrations were undetectable in non-reproductively active females whereas post-gravid females exhibited variable but relatively low values. Vitellogenic females had values just above detectable levels. Gravid females all exhibited a large increase in plasma progesterone concentration. Fence lizards had the lowest mean value during gravidity.

\section{Discussion}

The vascular changes exhibited by lizards of all 3 species occurred in the oviducal capillaries only. Whether this is due to the formation of new capillaries or the opening of pre-existing capillaries could not be ascertained. Additionally, vascularity of the gravid oviduct was greater than that observed during vitellogenesis. These data are similar to those obtained by Guillette \& Jones (1985) who observed that capillary density increased primarily around the uterine glands and at the interface of the luminal epithelium and lamina propria. Guillette \& Jones (1985) suggested that hypervascularity in oviparous species may be due to (1) increased glandular activity associated with shell secretion and/or (2) the need to supply gas exchange during embryonic development in utero. Previous studies have noted oviducal hypervascularity during vitellogenesis and gravidity in oviparous lizards and snakes (for review, see Yaron, 1985). Oviducal hypertrophy and hypervascularity during vitellogenesis is partly due to oestrogens secreted by the follicles (for review, see Lance \& Collard, 1978; Licht, 1984). Additional oviducal hypertrophy and hypervascularity as well 
as maintenance of existing levels during gravidity is probably in response to progesterone from the corpora lutea (for review, see Saidapur, 1982; Xavier, 1987). We noted that maximal capillary density occurred when plasma progesterone concentrations were maximal. These data suggest that progesterone may be angiogenic or may stimulate the release of angiogenic factors. However, increased vascularity may be due to increased glandular activity associated with shelling (Guillette \& Jones, 1985).

Egg retention is a transitional state for the evolution of viviparity (Tinkle \& Gibbons, 1977; Packard et al., 1977; Shine \& Bull, 1979; Guillette et al., 1980; Guillette, 1982a, 1985; Yaron, 1985). Viviparity has evolved independently almost 100 times in squamates (lizards and snakes) (Shine, 1985). Many squamates exhibit egg retention in utero to a relatively late stage (Zehr (1962) embryonic stage 30-35) as a normal characteristic of oviparity (Shine, 1983) and this ability has been suggested as a major preadaptation for viviparity (Guillette, 1985; Shine, 1985). The evolution of reptilian viviparity requires the formation of a placenta for gas and/or water exchange (Weekes, 1935; Guillette, 1982a; Guillette \& Jones, 1985). That is, oxygen consumption increases slightly during early gravidity in oviparous lizards (Sceloporus aeneus: Guillette, 1982c) but increases significantly in viviparous lizards and snakes (Clausen, 1936; Guillette, 1982c; Birchard et al., 1984). Embryonic maintenance, specifically gas exchange, may therefore require hypervascularity. Water transport is another embryonic requirement which may be supplied in part by uterine hypervascularity. In the present study we have observed that in 3 oviparous species, vitellogenesis and gravidity are characterized by increasing oviducal capillary density in the anterior uterus where eggs are incubated and shelled. Placentation occurs in this uterine region in viviparous forms (see, Guillette \& Jones, 1985; Yaron, 1985). Maximal capillary density occurred during gravidity in all 3 species and the mean density achieved was essentially the same; that is, about $30-35$ capillaries $/ \mathrm{mm}^{2}$. However, the collared lizard lays eggs with small blastodiscs whereas the great plains skinks lay eggs after embryonic development is half complete. The vascular densities observed in this study are almost identical to those reported by Guillette \& Jones (1985) for the viviparous lizard, Sceloporus bicanthalis, which has a simple Weekes Type I chorio-allantoic placenta (Weekes, 1935) with no erosion of maternal or fetal epithelial layers. These values are almost twice as great as those reported for the egg retaining species Sceloporus aeneus (Guillette \& Jones, 1985). Fox (1984) observed not only lower capillary densities for the collared lizard, $C$. collaris, and the skink, $E$. obsoletus, than we found, but noted a decrease in vascular density in the anterior uterus during gravidity. She obtained density estimates by examining histological sections stained to distinguish red blood cells (RBCs) in the capillaries. This technique may have underestimated actual vascular density if RBCs were washed from the sections during preparation. Moreover, during gravidity, the oviduct is stretched by the presence of the egg, making blood vessels difficult to see (especially capillaries just below the uterine luminal epithelium and among the shell glands). Our results therefore suggest that previous studies using this methodology may have underestimated vascular density by as much as $50 \%$.

The uterus of viviparous lizards exhibits a complete loss or extensive reduction of most of the shell glands and becomes a very thin $(10 \mu \mathrm{m}$ thick) vascular membrane with readily visible capillaries (Weekes, 1935; Guillette et al., 1981; Guillette \& Jones, 1985; Stewart, 1985). This thin membrane with little muscle or connective tissue allows an unobstructed view of most of the capillaries. The data presented above suggest that the evolution of simple placentation in lizards may not require additional hypervascularity than that already occurring in oviparous forms. Placentation, therefore, would primarily involve the loss of the shell membranes and shell glands which interfere with exchange. Additional studies examining uterine vascularity in viviparous species exhibiting simple placentae are needed to test this hypothesis. The evolution of reptilian viviparity does not appear possible without the simultaneous evolution of a placenta for gas and water exchange (Guillette \& Jones, 1985). The data presented here for 3 species of oviparous lizards indicate that squamates may be preadapted for viviparity and placentation because they exhibit uterine hypervascularity to a degree similar to that observed during simple placentation. 
We thank Dr Howard Bern for assistance with casting methods and discussion of this project; Dr Harry Rounds for use of laboratory facilities; M. Rand and D. Dickey for help in field collecting; M. Rand for assistance with the RIAs; and V. DeMarco for helpful comments on earlier versions of the manuscript.

\section{References}

Baker, L.A., Weathers, W.W. \& White, F.N. (1972) Temperature induced peripheral blood flow changes in lizards. J. comp. Physiol. 80, 313-323.

Birchard, G.F., Black, C.P., Schuett, G.W. \& Black, V. (1984) Influence of pregnancy on oxygen consumption, heart rate and hematology in the garter snake: implications for the 'cost of reproduction' in livebearing reptiles. Comp. Biochem. Physiol. 77A, 519523.

Brooks, B. (1906) The anatomy and internal urogenital organs of certain North American lizards. Trans. Tex. Acad. Sci. 8, 23-38.

Christiansen, J.L. (1973) Natural and artificially induced oviductal and ovarian growth in two species of Cnemidophorus (Sauria, Teiidae). Herpetologica 29, 195-204.

Clausen, H.J. (1936) The effect of aggregation on the respiratory metabolism of the brown snake Storeria dekayi. J. cell comp. Physiol. 8, 367-386.

Duvall, D., Guillette, L.J., Jr \& Jones, R.E. (1982) Environmental control of reptilian reproductive cycles. In Biology of the Reptilia, Vol. 13, pp. 201232. Eds C. Gans \& F. H. Pough. Academic Press, New York.

Fawcett, J.D. (1975) Effects of season, ovariectomy and hormone replacement therapy on the oviduct of Anolis carolinensis (Reptilia: Iguanidae). Ph.D. dissertation, University of Colorado, Boulder.

Fitch, H.S. (1955) Habits and adaptations of the great plains skink (Eumeces obsoletus). Ecol. Mon. 25, 59 83.

Fitch, H.S. (1956) An ecological study of the collared lizard (Crotaphytus collaris). Univ. Kansas Publs; Mus. Nat. Hist. 8, 213-274.

Fitch, H.S. (1970) Reproductive Cycles of Lizards and Snakes. Univ. Kansas Mus. Nat. Hist., Misc. Publ. 52, I-247.

Fox, H. (1977) The urogenital system of reptiles. In Biology of the Reptilia, Vol. 6, pp. 1-157. Eds C. Gans \& T. S. Parsons. Academic Press, New York.

Fox, S. (1984) Ovarian and oviductal morphology during the reproductive cycle of two lizard species, Crotaphytus collaris and Eumeces obsoletus. M. Sc. thesis, Wichita State University, Wichita.

Gerrard, A.M. (1974) Placental transfer of steroids at different stages of development and its possible implications in the sexual differentiation of Thamnophis radix haydenii embryos. Ph.D. dissertation, University of Colorado, Boulder.

Guillette, L.J., Jr (1982a) The evolution of viviparity and placentation in the high elevation lizard Sceloporus aeneus. Herpetologica 38, 94-103.

Guillette, L.J., Jr (1982b) A physiological (Ringer's) solution for anoline lizards. Herp. Rev. 13, 37-38.
Guillette, L.J., Jr (1982c) Effects of gravidity on the metabolism of the reproductively bimodal lizard, Sceloporus aeneus. J. exp. Zool. 223, 33-36.

Guillette, L.J., Jr (1985) The evolution of egg retention in lizards: A physiological model. In Biology of Australasian Frogs and Reptiles, pp. 379-386. Eds G. Grigg, R. Shine \& H. Ehmann. Royal Zoological Society of NSW, Sydney.

Guillette, L.J., Jr \& Jones, R.E. (1985) Ovarian, oviductal and placental morphology of the reproductively bimodal lizard, Sceloporus aeneus. J. Morph. 184, 8598.

Guillette, L.J., Jr, Jones, R.E., Fitzgerald, K.T. \& Smith, H.M. (1980) Evolution of viviparity in the lizard genus Sceloporus. Herpetologica 36, 201-215.

Guillette, L.J., Jr, Spielvogel, S. \& Moore, F.L. (1981) Luteal development, placentation and plasma progesterone concentration in the viviparous lizard Sceloporus jarrovi. Gen. comp. Endocr. 43, $20-29$.

Guraya, S.S. \& Varma, S.K. (1974) Morphology of ovarian changes during the reproductive cycle of the house lizard Hemidactylus flaviviridis. Acta morph. neer.-scand. 14, 165-192.

Hall, R.J. (1971) Ecology of a population of the great plains skink (Eumeces obsoletus). Univ. Kansas Sci. Bull. 49, 359-387.

Hall, R.J. (1972) Food habits of the great plains skink (Eumeces obsoletus). Am. Midl. Nat. 87, 258-263.

Humason, G.L. (1979) Animal Tissue Techniques, 4th edn. W. H. Freeman and Company, San Francisco.

Hunsuck, E.E. (1968) A method of quantitatively analyzing the microcirculatory architecture of the mandible: a preliminary report. J. Oral Surg. 26, 449-452.

Jones, R.E., Summers, C.H., Austin, H.B., Smith, H.S. \& Gleason, T. (1983) Ovarian, oviductal and adrenal vascular connections in female lizards (Anolis carolinensis). Anat. Rec. 206, 247-255.

Lance, V. \& Callard, I.P. (1978) Hormonal control of ovarian steroidogenesis in nonmammalian vertebrates. In The Vertebrate Ovary: Comparative Bio$\log y$ and Evolution, pp. 361-407. Eds R. E. Jones. Plenum Press, New York.

Larson, E.J. \& Van de Velder, R.L. (1969) Studies on pulmonary microcirculation of the common bull snake (Pituophis sayi sayi). Proc. 5th Europ. Conf. Microcirc., Bibliotheca Anatomica 10, 278-280.

Licht, P. (1984) Reptiles. In Marshall's Physiology of Reproduction, Reproductive Cycles of Vertebrates, 4th edn, Vol. 1, pp. 206-282. Ed G. E. Lamming. Churchill Livingstone, London.

Mead, R.A., Eroschenko, V.P. \& Highfill, D.R. (1981) Effects of progesterone and estrogen on the histology of the oviduct of the garter snake, Thamnophis elegans. Gen. comp. Endocr. 45, 345-354. 
Packard, G.C., Tracy, C.R. \& Roth, J.J. (1977) The physiological ecology of reptilian eggs and embryos, and the evolution of viviparity within the class Reptilia. Biol. Rev. 52, 71-105.

Saidapur, S.K. (1982) Structure and function of postovulatory follicles (corpora lutea) in the ovaries of nonmammalian vertebrates. Int. Rev. Cytology 75, 243-285.

Shine, R. (1983) Reptilian reproductive modes: the oviparity-viviparity continuum. Herpetologica 39, 1-8.

Shine, R. (1985) The evolution of viviparity in reptiles: an ecological analysis. In Biology of the Reptilia, Vol. 15, pp. 605-694. Eds C. Gans \& F. Billet. Wiley Interscience, St Louis.

Shine, R. \& Bull, J.J. (1979) The evolution of livebearing in lizards and snakes. Am. Nat. 113, 905-923.

Soewarmoto, I.N. \& Bern, H.A. (1958) The effect of hormones on the vascular pattern of the mouse mammary gland. Anat. Rec. 35, 403-435.

Stewart, J.R. (1985), Placentation in the lizard Gerrhonotus coeruleus with a comparison to the extra embryonic membranes of the oviparous Gerrhonotus multicarinatus (Sauria, Anguidae). J. Morph. 185, 101-114.

Tinkle, D.W. \& Gibbons, J.W. (1977) The distribution and evolution of viviparity in reptiles. Misc. Publ. Mus. Zool. Univ. Mich. 154, 1-55.

Trauth, S.E. (1978) Ovarian cycle of Crotaphytus collaris from Arkansas with emphasis on corpora albicantia, follicular atresia, and reproductive potential. $J$. Herpetol. 12, $461-470$.
Veith, W.J. (1974) Reproductive biology of Chameleo pumilis pumilis with special reference to the role of the corpus luteum and progesterone. Zool. Africana 9, 161-183.

Weekes, H.C (1935) A review of placentation among reptiles with particular regard to the function and evolution of the placenta. Proc. zool. Soc. London 1935, 625-645.

Xavier, F. (1987) Functional morphology and regulation of the corpus luteum. In Hormones and Reproduction in Fishes, Amphibians, and Reptiles (in press). Eds D. O. Norris \& R. E. Jones. Plenum, New York.

Yaron, Z. (1971) Observation on the granulosa cells of Acanthobrama terrae-sanctae and Tilapia nilotica (Teleostei). Gen. comp. Endocr. 17, 247-252.

Yaron, Z. (1972) Endocrine aspects of gestation in viviparous reptiles. Gen. comp. Endocr., Suppl. 3, 668674.

Yaron, Z. (1985) Reptilian placentation and gestation: structure, function and endocrine control. In Biology of the Reptilia, Vol. 15, pp. 527-603. Eds C. Gans \& F. Billet. Interscience, St Louis.

Zehr, D.R. (1962) Stages in the normal development of the common garter snake, Thamnophis sirtalis sirtalis. Copeia 1962, 322-329.

Received 1 July 1986 